\title{
Is Discord Detrimental? Using Institutional Variation to Identify the Impact of Public Governing Board Conflict on Outcomes
}

\author{
Jason A. Grissom \\ Vanderbilt University \\ jason.grissom@vanderbilt.edu \\ $* * *$
}

Few studies have examined the impact of governing board decision processes on board and organizational outcomes. This study draws on research on small work teams in the private sector to develop expectations about the relationship between outcomes and one aspect of board dynamics that affects decision-making: intra-board conflict. Using administrative and survey data from school board members and school district superintendents in California, I show a consistent pattern of negative associations between board conflict and outcomes at multiple organizational levels. An instrumental variables strategy utilizing institutional variation in board member election type confirms that board conflict can lead to negative outcomes. The findings suggest that existing conceptualizations of board roles should be broadened to incorporate the interpersonal dynamics that inform board decision-making.

What factors lead some citizen boards to be more effective than others? This question is an important one for public administration research because many kinds of public organizations are governed by small boards elected or appointed to set organizational policy and provide oversight of organizational operations. City councils, county boards of supervisors or commissioners, and municipal boards overseeing specific policy areas, such as health or zoning, are all examples of small citizen boards given central roles in public governance at the local level alone; other examples at regional or state levels of government abound as well. Unfortunately, investigation of governing board effectiveness in the public arena has been relatively meager, lagging far behind similar inquiry in the nonprofit and, especially, the private sectors (e.g., Brown 2005; Pearce and Zahra 1991; Pfeffer and Salancik 1978). Research on boards of trustees in these literatures has long recognized that governing boards impact their organizations by helping overcome principal-agent problems through monitoring or by providing expertise to managers (Daily, Dalton, and Cannella 2003). More recently, however, researchers have begun to emphasize the importance of board decision-making processes for organizational success. At a fundamental level, boards are small 
groups who must make collective decisions about organizational policies and strategies, suggesting that research on small group decision-making in other settings has implications for governing boards. As Forbes and Milliken (1999) hypothesize, "effectiveness of boards is likely to depend heavily on social-psychological processes, particularly those pertaining to group participation and interaction, the exchange of information, and critical discussion” (492). From this perspective, impediments to constructive group interactions interfere with the board's ability to set effective policies and make strategic adjustments in response to environmental changes, in turn potentially harming organizational outcomes (Goodstein, Gautam, and Boeker 1994).

Extending this line of research, this study examines one such potential impediment to public governing board decision-making: conflict among board members. A large body of empirical work, primarily from the study of work teams in private firms, suggests that intragroup conflict may have implications for board effectiveness (e.g., De Dreu and West 2001; Jehn 1995; Jehn, Northcraft, and Neale 1999). In theory, these effects may be either negative or positive. On one hand, conflict may interfere with board performance by creating antagonism and anxiety that distract the board's attention and impede decision-making (Amason 1996). On the other hand, conflict may lead board members to question assumptions, scrutinize issues, and challenge one another to think creatively (Jehn 1994), which may improve outcomes. Anecdotal evidence and discussions in popular board governance texts (e.g., Carver 2006) suggest that conflict negatively affects board effectiveness, but the connection between governing board conflict and board or organizational outcomes has not been addressed systematically, in management research in the public sector or elsewhere. As a result, it is unclear that investments in training or consultant services aimed at conflict amelioration are worth the time and expense boards often allocate to them.

A primary challenge to the study of board conflict or board decision-making more generally is gaining access to process-oriented data (Daily, Dalton, and Cannella 2003). This study's solution 
to this difficulty is to collect data via an original matched survey of school board members and superintendents that is then linked to administrative data from a random sample of school districts in California. School districts are a useful arena for this analysis for several reasons. First, they utilize the board-executive governance structure that is common to many public organizations, particularly at the local level. Second, most school districts tend to be organized similarly administratively, which helps ensure that any associations observed between boards and outcomes are not driven by differences in organizational form. Third, school districts share a common primary goal—raising student achievement—for which substantial performance data in the form of student test scores have become readily available in recent years.

Drawing on group conflict research in the private management field, this study develops expectations concerning the impact of board conflict on board and organizational outcomes. In particular, it hypothesizes that board conflict will negatively impact (1) the board's capacity to make effective decisions and provide oversight to the organization; (2) the board's working relationship with its chief executive officer (CEO); and (3) both intermediate and final organizational outcomes.

These expectations are then tested in a multivariate framework. The analysis has three important strengths. First, it takes advantage of exogenous institutional variation that prior work has shown to drive intragroup conflict to get close to causal estimates via instrumental variables (IV). The use of IV estimation is necessary in this context because we might expect unobserved challenges in the organizational environment to impact both board conflict and outcomes, potentially biasing the estimates of the effects of board conflict. Second, the matched boardsuperintendent data allows dependent and independent variables to come from different sources, overcoming spurious correlations from common source bias and allowing the robustness of the results to be assessed. Finally, the analysis utilizes both subjective outcome measures (e.g., ratings 
of board-executive relations) and objective ones (e.g., district performance on standardized tests) at multiple levels of the organization, providing a more complete accounting of the impacts of governing board conflict than would be available with a narrower set of dependent variables.

\section{Governing Board Conflict}

While the cognitive and interpersonal processes that characterize conflict are potentially complex (Thomas 1992), the underlying notion is simple: conflict is a pattern of feelings, actions and reactions that result when "one party perceives that its interests are being opposed or negatively affected by another party” (Wall and Callister 1995, 517). For work groups, De Dreu and Weingart (2003) described conflict as a "process resulting from tension between team members because of real or perceived differences” (741). Recognition that conflict is a pattern or process emphasizes a time dimension that distinguishes conflict from simple disagreement. This distinction is especially important in the study of governing board members who must continually interact with one another to make decisions over a long time period, creating repeated opportunities both to generate and to be affected by conflict among members.

Substantial research explores the determinants of group conflict and its impacts on group outcomes (see Wall and Callister 1995, for a review). Most relevant to the study of governing boards is research examining conflict on work groups in firms. Like boards, firm work groups are small, tasked with collaborating to achieve collective goals, and influenced by their organizational context (Ihrke and Niederjohn 2005). Because of these similarities, scholars have highlighted the need to investigate central findings from work group studies, particularly pertaining to the effects of interpersonal dynamics on group outcomes, in the context of board decision-making (Forbes and Milliken 1999). 
Work group research has highlighted multiple factors that drive sustained disagreement among members of small groups. For example, groups charged with accomplishing more difficult, less routine tasks or who operate in more uncertain environments experience greater conflict (Jehn, Northcraft, and Neale 1999). Such circumstances create more frequent opportunities for disagreement over action (Wall and Callister 1995). Research suggests that task environment difficulty affects conflict on governing boards as well, as with Merz's (1986) finding that conflict was more apparent on school boards facing financial distress. Another key predictor of group conflict is diversity of group member preferences over group action. The presence of multiple preferences increases the number of alternatives that must be examined, making reaching consensus more difficult (Amason and Schweiger 1994). Group members with similar preferences also are more likely to prioritize and interpret information in similar ways and to identify with one another more easily, reducing conflict (Jehn 1994; Jehn, Chadwick, and Thatcher 1997).

In the context of public governing boards, preferences over group action often means preferences over policies; thus, factors that contribute to heterogeneity of member policy preferences may contribute to board conflict indirectly (Grissom 2010). One such factor that researchers have noted is whether board members are elected in single-member district—or ward— elections rather than in at-large elections. Median voter models predict that the preferences of elected representatives tend toward the median preference of their constituents (Black 1958; Downs 1957). In at-large elections, each school board member represents the same median voter, so the model predicts that preferences among members will be relatively homogeneous. In contrast, board members elected by sub-district will each represent a different median voter. To the extent that the preferences of those voters vary, perhaps due to socioeconomic segregation across neighborhoods, single-member election types will predict greater preference diversity. Research on city councils (Welch and Bledsoe 1988) and school boards (Danzberger 1994; Kirst 1994) suggest that single- 
member elections indeed are associated with greater governing board disagreement. As described later, the link between election type and board conflict is an important component of the estimation strategy employed in this study because election type is an exogenous institutional feature that can be used to identify the impact of board conflict on outcomes.

\section{Conflict and Decision Quality}

The broad question for this study is whether board conflict enhances or impedes board effectiveness. Because of the board's strategy and policy roles in the organization, decision quality-i.e., the board's ability to consistently make strategy and policy choices that advance the interests of the organization-is a central component of effectiveness. Boards that can consistently work together to aggregate information, assess alternatives, and arrive at "better" policy decisions seem likely to outperform boards that are able to do so less consistently.

The question of whether intragroup conflict systematically affects the quality of group decisions has generated a good deal of attention in the research on small work groups. Early studies focused primarily on the negative effects of conflict on decisions (see Wall and Callister 1995). These studies suggested that conflict negatively impacts decision quality by discouraging individual team members from fully engaging in the decision-making process, therein reducing the number of perspectives and potential solutions brought to the table (Amason 1996). Furthermore, for individuals, the perception of a hostile environment interferes with cognition, inhibiting creativity and promoting inflexibility (Carnevale and Probst 1998). In decision sciences parlance, the team's information processing capacity is disrupted.

More recently, scholars began to distinguish between task and relationship conflict and to hypothesize that the former (though not the latter) may improve outcomes by encouraging greater deliberation and innovation around solutions to task challenges (Amason and Schweiger 1997; Jehn 1994, 1995). The deliberation and innovation effects of conflict were assessed to be especially 
beneficial in complex, uncertain task environments without ready solutions (Jehn 1997), which are often the contexts in which governing boards operate. However, in a review of quantitative studies linking task and relationship conflict to work team performance since 1995, De Dreu and Weingart (2003) called into question the shift toward conceptualizing conflict as potentially positive. Across 25 studies, their meta-analysis found negative correlations of similar magnitudes between team performance and relationship conflict $(r=-0.25)$ and task conflict $(r=-0.20)$, leading the authors to conclude that "both task conflict and relationship conflict are equally disruptive" to group decisionmaking (746). Also, when the authors considered the moderating impact of task complexity on the conflict-performance relationship, they found that, on average, this moderating effect occurred in the wrong direction, with more negative conflict effects occurring for teams with more complex tasks. $^{1}$

From the perspective that governing boards are small work groups who function in large part to choose appropriate policies and strategies, the work group literature suggests that intragroup conflict creates disruptions in information processing and strategic decision making that translate into less effective policy outputs (Forbes and Milliken 1999). In other words, conflict among board members leads to lower quality board decisions and lower board effectiveness. Consistent with this expectation, studies of nonprofit boards of trustees have found board members' assessments of interpersonal conflict to be negatively associated with ratings of board effectiveness provided by the CEO (Bradshaw, Murray, and Wolpin 1992) or the members themselves (Cornforth 2001). Similarly, case studies of school boards in nine school districts showed that interpersonal differences and an inability to work as a team hindered effective governance (Carol et al. 1986).

\footnotetext{
${ }^{1}$ Besides the similar magnitude of negative effects of task and relationship conflict on decision quality, the high correlation between the two types makes differentiation of limited practical importance. De Dreu and Weingart (2003) found that the average correlation between the two across studies was 0.54 , suggesting low differential validity (744). This finding confirms earlier observations that task and relationship conflict often occur together, with the negative effects of the second dominating any potential positive effects of the first (Amason 1996, 129).
} 


\section{Maintaining a Positive Working Relationship with the Executive}

Aside from its ability to reach effective collective decisions, a secondary aspect of board effectiveness is the degree to which it maintains positive working relations with its top executive. Resource dependence theory views the board as a resource for the organization (Pfeffer and Salancik 1978). From this perspective, organizational theorists suggest that a central function of the governing board is to support the chief executive by providing guidance and allowing management to draw on its collective expertise through the advice-and-counsel role (Hillman and Dalziel 2003).

A good relationship with the chief executive is essential for the board to perform its adviceand-counsel function. Poor board-executive relations discourage the exchange of candid advice and feedback and impede communication and cooperative problem-solving (Westphal 1999). Boards rely on managers to keep them informed about organizational matters and facilitate relations between the board and both internal and external stakeholders (Björk 2008). Moreover, poor relations may make it more difficult for the board to gather good information from the executive on his or her behavior, impeding the monitoring function that agency theorists see as the board's primary responsibility (Daily, Dalton, and Cannella 2003). For these reasons, a positive working relationship with the board's executive is likely to be an outcome the board values.

Prior studies posit that intra-board conflict may spill over and damage the board-executive relationship (Gabris et al. 2000). Conflict among board members generates anxiety and frustration and can embroil management in board disagreements. Sundaramurthy and Lewis (2003) suggested that conflict may "trigger political battles that undermine social ties and fuel distrust" among board members and managers (408). In their study of local government boards in regions of Illinois and Wisconsin, Gabris et al. (2000) found that board conflict correlated with poor communication between boards and staff members and staff discomfort with and distrust of the board. Poor 
relations with management and other staff may reduce the human or social capital resources on which the board can draw when faced with challenges.

\section{Impacts on Organizational Outcomes}

If intragroup conflict negatively impacts proximal board outcomes such as the quality of board policy decisions and the relationship between the board and the CEO, it is possible that conflict indirectly affects outcomes more removed from the board, including, potentially, organizational performance. There could be numerous pathways connecting board conflict to the performance of the organization. For example, from a resource dependence theory perspective (Hillman and Dalziel 2003), board conflict could hurt board-CEO interactions, which undermines that advice-and-counsel function, which in turn lowers CEO performance, which negatively affects implementation choices made by middle management, and so forth. Alternatively, board conflict may decrease the job satisfaction of top managers and, in turn, increase management turnover, which research has shown can hurt organizational performance (e.g., Kacmar et al. 2006). Another possibility is that high-conflict boards simply make worse policy decisions for the organization, which has consequences for its results. Moreover, such processes may be overlapping and even reinforcing. The potentially large number mediating pathways and the accompanying complexity make mapping the impacts of board conflict on even intermediate organizational outcomes difficult. Still, impacts on organizational outcomes may be the most important accounting of the effects of board conflict, making this an important connection to consider.

Unfortunately, research in this area is scarce. The work group literature is not especially informative here because those studies have focused solely on the group’s performance, not on outcomes for the organization. A few studies in the public and nonprofit spheres have considered the relationship between board functioning and organizational performance. For example, through their interviews with higher education boards of trustees, Chait, Holland, and Taylor (1991) 
identified strong interpersonal dynamics as a predictor of positive organizational outcomes. Brown's (2005) study of survey data from nonprofit boards in the United Kingdom similarly found that boards with strong collegial relationships perceived greater organizational performance. Those organizations also were more likely to have sound finances, though this outcome was not evaluated in a multivariate framework. In case studies of school boards, Goodman, Fulbright, and Zimmerman (1997) surmised that districts with negative relationships, poor communication and a lack of trust among governance actors (i.e., board and superintendent) also had lower student achievement outcomes.

In short, there is some precedent for the expectation that board conflict may have negative impacts on organizational outcomes. Because board decision-making is more likely to affect proximal outcomes, it is important to consider intermediate and final organizational outcome variables. For example, in the context of school districts, we might look for impacts at the teacher level in addition to only examining student outcomes.

The remainder of this paper tests the general expectation supported by prior management research that intra-board conflict negatively impacts public governing board effectiveness. More specifically, it tests the hypotheses developed above that higher board conflict reduces the board's governance effectiveness, hurts its relationship with its CEO, and negatively affects organizational outcomes. Using a unique data set from school board members and superintendents in California that contains multiple measures of both board conflict and board effectiveness, the analysis aims to provide insight into board decision-making that has not been available in prior studies. It also utilizes institutional variation in conflict in an estimation strategy that gets closer to establishing a causal relationship. The next section describes the data and lays out this strategy.

\section{Data and Methods}




\section{Survey Samples}

During the 2005-06 academic year, paper questionnaires were mailed to each member of 222 of California’s 975 local boards of education. ${ }^{2}$ California is an attractive setting for this study because of its diversity and size, educating approximately one-eighth of all public school students in the United States. Districts were randomly sampled after stratifying by district enrollment size, and responses were solicited from every member of each board drawn into the survey sample. The questionnaire, which was developed based on prior school board surveys and in consultation with school board members in the San Francisco Bay Area, covered school board member attitudes, time use, background and assessments of board decision-making. Subjects were mailed up to three surveys plus a postcard reminder over a six-week period to encourage them to respond; no other inducement was provided. For the 1,111 school board members sampled, the response rate was 63 percent $(\mathrm{N}=703)$. For comparison, in a national survey of school board members, Hess (2002) achieved a response rate of 41 percent.

A shorter questionnaire was mailed to the superintendents in the same 222 school districts. The response rate for the superintendents was 71 percent $(\mathrm{N}=157)$. While the survey focused on the work of the superintendent, it contained a set of questions specifically pertaining to the work of the school board designed to be consistent with questions on the school board survey. Because board members' assessments of the study's central constructs could be unreliable—if, for example, board members have a difficult time specifying how much conflict they experience or tend to overestimate their own effectiveness — using independent measures from both the board and superintendent improves the credibility of the empirical results.

\footnotetext{
${ }^{2}$ Using student test score data to measure performance necessitated limiting the analysis to a single state, since each state maintains its own student testing regime.
} 
School board member responses were averaged at the board level. Averaging responses was appropriate because board conflict is a group-level variable. Aggregating individual responses to the board level also helped alleviate concerns about measurement error and undue influence from outliers. Matching these boards with superintendent responses yielded an analytic sample of 124 school districts, though item non-response resulted in slightly smaller sample sizes in some models. Among these 124 districts, the median number of board member responses was 3, while the modal number was 4 . Thirteen boards had only one school board member response; these boards were kept in the sample to avoid the loss of sample size. A sensitivity analysis including only boards with at least two respondents produced very similar results to those reported below.

\section{Measures of Intra-Board Conflict}

Two types of survey responses were used to capture intra-board conflict or its converse, board consensus. The first pertains to divisiveness in decision-making. In particular, school board members were asked, "What percent of school board decisions are characterized by division among board members?” Decision-making conflict was operationalized as the percentage indicated. As shown in Table 1, which reports descriptive statistics for all variables used in the analysis, the average percentage reported is $9.4 \%$. This low mean is consistent with prior work noting that most school board decisions are routine and made with a large degree of unanimity (Polinard et al. 1994). There is, however, relatively large variance in this measure (standard deviation $=12.31)$, suggesting that, while low conflict is the norm, decision-making in some boards is marked by much higher levels of disagreement. Similarly, a Likert scale response item was included on the superintendent survey that asked respondents their level of agreement with the statement, "My school board's policy decisions are almost always characterized by consensus and agreement.” The mean response is 4.0 out of 5 , with 5 indicating "strongly agree," though again there is substantial variation (standard deviation $=1.1)$. The correlation between the two measures is approximately -0.50 , 
indicating that the board's assessment of conflict and the superintendent's assessment of consensus tend to move together relatively closely—albeit obviously in opposite directions—and that it is reasonable to view the two measures as capturing opposite sides of the same coin. ${ }^{3}$

\section{Measures of Board and Organizational Outcomes}

The main question for this study is whether higher intra-board conflict is associated with lower board and organizational outcomes. To answer this question, the study employed both subjective and objective measures of board and organizational performance.

Assessment of board governance effectiveness. On the survey, board members were asked their agreement with the statement "My school board governs effectively," again on a five point scale. The average response is 4.2. Superintendents also were asked to assess board effectiveness by responding to the same statement; the mean response is 4.1. The correlation between the two measures is 0.58 , suggesting that the school board members and superintendents tend to have a relatively high degree of agreement on the board's level of effectiveness. ${ }^{4}$

Board-executive relations. A specific area of board functioning that prior work suggested to be affected by increased intra-board conflict is maintenance of the relationship with the board's chief executive. School board members were asked to assess the degree to which "My school board has a good working relationship with the district’s current superintendent.” Similarly, superintendents were asked to respond to the statement "I have a good working relationship with

\footnotetext{
${ }^{3}$ As a further check on the conflict assessment measures, I also checked their correlations with an additional assessment on each survey: the degree to which the board or superintendent reports that the board "works together well." As expected, the conflict and working together measures were highly correlated (-0.72 between board's assessment of conflict and board's assessment of working together, and 0.66 between the superintendent's consensus and working together assessments).

${ }^{4}$ We may still be concerned that a single-item measure of board governance effectiveness-or the other outcome measures-may contain substantial measurement error. Since these measures are used as dependent variables, however, the implications are less serious. Measurement error will lead to inflated standard errors for the variables in the model (i.e., lower efficiency), making statistical significance more difficult to obtain, but coefficient estimates will not be biased (Wooldridge 2002).
} 
my school board." School board members' mean response is 4.4. Superintendents' mean response is 4.5. The correlation between the two is 0.49 .

Teacher turnover. Employee turnover typically is described as a negative outcome for organizations (Mobley 1982). Teacher turnover is useful for assessing the impact of board conflict on an intermediate organizational outcome, since prior work has shown that the work decisions of teachers and other street-level workers are responsive to organizational management (e.g., Grissom, 2011; Bertelli 2007; Cotton and Tuttle 1986; Ingersoll 2001). Unfortunately, California’s administrative records do not contain an actual teacher turnover measure. Instead, a Likert scale response item from the school board survey, "Teacher turnover is a significant problem in my district," is used to approximate the severity of teacher turnover. ${ }^{5}$

Student achievement. A primary performance objective for school districts, particularly in the current era of test score-driven school accountability, is raising student achievement. Thus an aggregated index based on student test score performance is used to evaluate the potential association between intra-board conflict and final organizational outcomes. The measure is one-year growth in the district's Academic Performance Index (API) score between the 2004-05 and 2005-06 academic years. It is important to use the change in test score performance rather than the level because, conceptually, performance levels are largely a function of student characteristics and other factors over which schools have little control, whereas performance growth captures the contribution schools make to student learning. ${ }^{6}$

The API is a composite score calculated for each school district by the California Department of Education (CDE) based on the district's performance on state standardized tests each

\footnotetext{
${ }^{5}$ This response item was not included on the superintendent survey.

${ }^{6}$ A better modeling strategy utilizes student-specific changes in test score performance from one year to the next, which is commonly called a "student value-added" model. Such a model allows for a more comprehensive set of controls and can take into account such important factors as student mobility in estimating organizational performance. Unfortunately, California does not maintain the kind of longitudinal student data base that would facilitate such an analysis.
} 
year. The score ranges from 200 to 1,000. Performance on a variety of tests across subjects and grade levels are combined to create the API score. These tests are not given the same weight in the API calculation from year to year, and, in fact, consecutive years' API scores may not even be based on the same set of assessments. As a result, it is not valid to create simple differences in yearly API level scores as a measure of district growth. However, each year CDE calculates a special one-year growth score that is the difference between this year's and last year's performance using identical metrics and weighting schemes. This API growth measure is used to approximate the degree to which the district was successful in raising student achievement during the year of the data collection. Average growth in the sample is 10.8 points, with a range of -72 points to 71 points.

\section{Control Variables}

Theories of governance emphasize that each variable in a governance system is situated within environmental and structural contexts apart from which individual pieces cannot be understood (Lynn, Heinrich, and Hill 2001). Thus, including relevant contextual factors in the models is important. These are drawn from California administrative data. Student demographic characteristics — percent black, percent Hispanic, and percent free or reduced price lunch eligible, a proxy for poverty—and district organizational characteristics—indicator variables for urban or rural location (with suburban as the omitted category), natural log of district size, average per-pupil spending, and whether the district is unified (K-12, as opposed to elementary or secondary only) are included in the models. Models include the percentage of adults in the district with college degrees and the district's median household income, obtained from the Census. Models also include the fraction of school board elections described as "very" or "moderately" competitive in school board survey responses, as a proxy for the level of activity in the board's electoral environment, 
which prior studies have found to be correlated with board conflict (Grissom 2010). ${ }^{7}$ A final control variable included in the models is the baseline API level in the preceding academic year (2004-05). Including the prior year's level is important to capture the impact of prior organizational performance on current outcomes. In the API growth analysis, including this variable is even more important because districts already scoring high on the API may have more difficulty exacting gains from students (so-called “ceiling effects”). A correlation matrix for the control variables is shown in the Appendix. ${ }^{8}$

\section{Estimation Strategies}

To test whether an association exists between intra-board conflict and measures of board and organizational performance, two estimation strategies are employed. The first is a series of standard multivariate regressions of each outcome measure on a measure of intra-board conflict and control variables, estimated via ordinary least squares (OLS). However, if there are unobserved factors that predict both board conflict and district outcomes, such as fiscal distress or rapid enrollment changes, estimates of the impact of board conflict obtained by OLS may be biased. Alternatively, bias could arise from reverse causality, as might be the case if a negative relationship with the superintendent leads to board disagreement, or from measurement error in the conflict measures,

\footnotetext{
7 Other choices were "occasionally" or "rarely."

${ }^{8}$ The correlation matrix shows that a number of the independent variables have correlations above 0.7. In particular, percent free/reduced lunch eligible is negatively correlated with last year's API score $(r=-0.72)$ and percent of adults who are college graduates $(r=-0.72)$, which is in turn negatively correlated with median household income at $r=-$ 0.82 . The main concern raised by these correlations is multicollinearity. Thus, I calculated variance inflation factors (VIFs) for the independent variables. The mean was just above 2.0, with percent college graduates as the variable with the highest individual VIF (5.7). To ensure that the regression results were not affected by including this variable, I dropped it from the models and re-estimated each table. The coefficients for the conflict and consensus variables were identical to 2 and sometimes 3 decimal places in every model, and statistical significance for these variables was never affected.
} 
which may be important given inaccuracies in recall or assessment—especially self-assessment—on survey instruments. ${ }^{9}$

To address these threats and get closer to causal estimates of the impacts of board conflict, the study employs an instrumental variables strategy that exploits institutional variation underlying preference heterogeneity on the board. This variation comes from differences in election types across school districts in California. Because single-member or ward elections are likely to induce preference diversity not induced by at-large elections, variation in election type can be used as an instrument for board conflict. Intuitively, IV uses only the part of the variation in conflict-i.e., the part that is uncorrelated with the potential sources of bias, such as some omitted variable- to identify the impact of conflict on outcomes, thus establishing the average causal among the population affected by the instrument.

This strategy only works if two conditions are satisfied. First, election type must be correlated with the independent variable of interest, i.e., board conflict. The strength of this relationship has been established in prior work (Grissom 2010) and can be further tested in the first stage of the IV estimates. Second, conditional on other variables in the model, election type must be uncorrelated with the error term in the regression of an outcome on board conflict, i.e., the instrument is exogenous. The exogeneity assumption cannot be tested directly, but election type is a plausible candidate to satisfy this assumption. Type of election used is largely a vestige of Progressive Era reform, which made at-large school board elections common. In the years following the Voting Rights Act of 1965, some at-large districts, particularly in urban areas, switched to single-member elections as a result of court challenges charging that at-large elections diluted minority votes and promoted racial disenfranchisement in local elections (e.g., Avila, Lee, and Ao

\footnotetext{
${ }^{9}$ So long as the measurement error in the board conflict measures are random, resulting bias is likely to be toward zero, meaning that the OLS coefficients are likely to be underestimates of the true association.
} 
2007; Welch, 1990). ${ }^{10}$ The facts that election type is largely historically determined and that recent changes are determined by factors other than board conflict or the kinds of outcomes we examine support the validity of the instrument. The next most likely threat to validity is the potential for election type to affect outcomes through some channel outside its effect on intra-board decisionmaking dynamics not accounted for by the control variables. For example, if single-member elections promoted community engagement with the school system, which in turn improved outcomes, the suitability of the instrument would be undermined. Such relationships are possible but difficult to assess; still, to which they or other violations exist will call into question the consistency of the IV estimates. ${ }^{11}$ See Wooldridge (2002: 83-107) for a complete discussion of the instrumental variables technique and its assumptions.

\section{Results}

\section{Assessments of Board Governance Effectiveness}

The first outcome variables examined for evidence of an association with board conflict were the ratings of board governance effectiveness provided by both the school board members and the superintendents. To avoid common source biases that might arise if both the dependent and main independent variables were derived from the same respondent, only models that regress the school board's (superintendent's) effectiveness rating on the superintendent's (school board's) conflict measure are presented. ${ }^{12}$ Table 2 shows the results, first for the superintendent's rating of board effectiveness and then for the school board's self-rating. OLS and IV results are given.

\footnotetext{
${ }^{10}$ Both the Voting Rights Act of 1965 and the California Voting Rights Act, signed in 2002, provide minority groups an avenue for relief if they can prove their votes are being diluted by at-large elections. The basis for claims against school districts under these laws is that voting in the district is "racially polarized," i.e., people tend to vote for candidates of the same race, which prevents minority groups from gaining representation on the school board (Avila, Lee, and Ao 2007). School district performance is not germane to these claims.

${ }^{11}$ Because we cannot know for sure whether this assumption (or the assumptions of the OLS models) is violated, both OLS and IV estimates are reported for comparison.

${ }^{12}$ Models using both dependent and independent variables from the same source yielded even stronger associations than those presented here.
} 
Because of the clear directional hypotheses regarding the relationship between conflict and outcomes, all hypothesis tests for conflict and consensus are one-tailed. ${ }^{13}$

All four models show strong support for the expectation that board conflict negatively impacts board effectiveness. Across models, conflict among school board members is negatively correlated with the rating of governance effectiveness, irrespective of which respondent provided the conflict or outcome measure. ${ }^{14}$ The coefficient in model 1 suggests that each additional percentage of decisions labeled as divisive by the school board members is associated with a decline of approximately 0.03 points on the superintendent's rating of the board's effectiveness $(p<0.01)$. This relationship is depicted graphically in the left panel of Figure 1 and shows that districts with very high conflict are rated substantially less effective than those with the relatively low conflict measures that characterize the typical district. The estimate obtained using IV to combat bias (model 2) is slightly larger in magnitude $(\beta=0.04)$ and statistically significant at the 0.01-level, implying that every 10 percentage point increase in divisive decisions leads to a fall in the superintendent's assessment falls of nearly half a Likert scale point. ${ }^{15}$

Models 3 and 4 show the results for the board's self-rating. The OLS model suggests that a one-point increase in the superintendent's consensus rating is associated with a 0.27-point increase in the board's rating of its effectiveness. The IV estimate of this increase is a bit higher $(0.39$ points). These estimates suggest that a one standard deviation increase in board consensus causes an

\footnotetext{
${ }^{13}$ Using a more conservative two-tailed test results in nearly identical conclusions.

${ }^{14}$ The paper's main results are robust to (a) replacing the board conflict measures with the working together measures described in footnote 3 and (b) using factor scoring to combine the conflict and working together assessments into a single measure.

${ }^{15}$ The first-stage F-statistic reported at the bottom of the second column $(F=16.9)$ is well above the cutoff of 10 proposed as a rule of thumb by Staiger and Stock (1997) for identifying weak instruments. The instrument performs similarly well for the superintendent consensus measure, as reported in column $4(F=11.7)$. These statistics alleviate concerns about bias from weak correlations between the instrument and the conflict measures in the first stage of the IV estimation. Note that the F-statistics reported in each table are identical because the first stage of the IV estimations is the same regardless of the dependent variable used in the second stage.
} 
increase in the effectiveness self-rating of about two-thirds of a standard deviation, or about 0.41 points. $^{16}$

\section{Board-Executive Relations}

Next we examine the quality of the working relationship between the board and the top executive in the organization, the district superintendent. Case study research on school districts has identified this relationship as “essential for effective governance” (Land 2002, 254). Once again, we take advantage of having evaluations of the board-executive relationship from both the board and superintendent perspective.

The results using the school board’s “percent divisive decisions” and the superintendent's policy consensus measure are shown in Table 3. Once again, the four models tell a similar story: boards with higher degrees of intragroup conflict have less positive relationships with the district superintendent. This relationship, as estimated in model 1, is shown in the right panel of Figure 1. The results are evident in both OLS estimates and grow somewhat larger in magnitude when IV is used instead. The IV result in model 2 implies that each additional percentage of divisive decisionmaking on the board lowers the rating of the board-superintendent relationship (as assessed by the superintendent) by about 0.04 Likert points. The coefficient in model 4 suggests that a one point increase in the consensus rating translates into a 0.31-point increase in the board's rating of its relationship with the superintendent. ${ }^{17}$

Because the conflict and consensus measures are on different scales, standardized beta values (not shown) are useful for comparing these two results. In model 2, a one standard deviation

\footnotetext{
${ }^{16}$ A number of control variables, though not reported in the tables, showed statistically significant associations with the superintendent's governance effectiveness rating (two-tailed tests). Percent free/reduced lunch students, unified districts, rural districts, and competitive elections were all negatively associated with the rating, while percent Hispanic was positive. However, in the models of the school board's rating, none of these measures reached conventional levels of statistical significance.

${ }^{17}$ In a sensitivity analysis in which we included only boards with two or more respondents, the coefficient in model 4 fell to 0.23 and was no longer statistically significant at conventional levels.
} 
increase in divisive decision making (approximately 12 percentage points) is associated with a decrease in the superintendent's rating of his or her relationship with the board of approximately 0.6 standard deviations, or approximately 0.39 Likert scale points. Using the school board's perspective on the board-executive relationship in model 4 returns a standardized beta of 0.49 , or roughly 0.32 Likert scale points. In other words, the two IV results yield very similar estimates of the negative impact of board conflict on relations between the board and chief executive. ${ }^{18}$

\section{Organizational Outcomes}

Finally, we turn to the two measures of organizational outcomes: the degree to which teacher turnover is a problem (intermediate outcome) and one-year student test score growth over the school year in which the surveys were administered (final outcome). The discussion of prior research suggested that intra-board conflict would be associated with decreased organizational performance, though it is reasonable to expect that this association might be weaker than those previously examined because of the indirect mechanisms linking these variables. Table 4 displays the results, again focusing on the school board's "percent divisive decisions" and the superintendent's policy consensus measure as the conflict measures.

Looking across the models, there is general but weak support for the hypothesized negative association between intra-board conflict and organizational performance. While statistical significance is not present in all models, every coefficient shown does have the hypothesized sign, though the relatively meager $R^{2}$ values suggest that many important factors are missing from the models. ${ }^{19}$ The first four models show the results for the school board's assessment of teacher

\footnotetext{
${ }^{18}$ Among the control variables, higher median incomes, greater electoral competitiveness, fewer Hispanic students, and being unified were each associated with lower ratings of superintendent-board relationships in the OLS models for either the board or superintendent's rating, though the patterns were not consistent across the OLS and IV estimates.

${ }^{19}$ Low $R^{2}$ values are not unsurprising given the large number of factors that likely contribute to organizational outcomes such as teacher turnover and student achievement.
} 
turnover. Models 1 and 2 show positive and statistically significant coefficients when the "percent divisive decisions" variable is used to measure board conflict, though some caution is warranted given that common source bias may be an issue, particularly in model 1 . Nonetheless, both results point to a small but positive relationship between board divisiveness and the degree to which teacher turnover is rated as problematic for the district.

This pattern continues when the superintendent's board consensus measure is used instead in models 3 and 4; consensus and turnover are inversely related. When IV is employed (model 4), the coefficient is quite large, suggesting that increasing the superintendent's consensus rating by one Likert point reduces the school board's rating of teacher turnover as a problem by about 0.6 Likert points $(p<0.01)$, on average.

The remaining four columns in Table 4 examine API growth. Here the results are weaker but perhaps suggestive. Using the school board's conflict measure in models 5 and 6, neither the OLS nor the IV estimate yields a statistically significant coefficient. For the models that use the superintendent's consensus measure, the coefficient is positive $(\beta=2.97)$ and significant at the 0.05-level in model 7, but it becomes small and statistically insignificant in the IV analysis (model 8). Still, the coefficients are all in the hypothesized direction. ${ }^{20}$ These results suggest that linking governing board conflict to final organizational outcomes is infeasible without large amounts of data, given the "distance" between the two variables within the organization, the indirect nature of the relationship, and the large number of other factors that predict a final outcome such as student performance. $^{21}$

\footnotetext{
${ }^{20}$ Having larger numbers of black and Hispanic students generally is associated with a higher likelihood that the board says that teacher turnover is a problem. Interestingly, however, none of the control variables are statistically significant in the API growth models at a conventional level. Additional tests suggested that the null coefficients are not the result of multicollinearity.

${ }^{21} \mathrm{CDE}$ also publishes API growth and level scores for different student subgroups. I ran versions of the API growth models separately for African Americans, Hispanics, whites, and a group CDE labels "socioeconomically disadvantaged" to test whether board conflict may be associated with differential organizational performance along
} 


\section{Discussion}

Drawing on literature suggesting that intragroup conflict decreases group functioning and worsens group outcomes, this study tested a series of hypotheses around the broad question of whether these conclusions can be applied to the policymaking work of governing boards. More specifically, it analyzed whether higher board conflict lowers board governing effectiveness, harms the relationship with the organization's CEO, and damages outcomes at different levels of the organization. Using public school boards as a test case, the analysis supported the conclusion that conflict among governing board members impairs board and—for some measures—organizational performance, though evidence regarding the latter point is less clear-cut. The link between board conflict and outcomes was evident using both subjective and objective outcome measures outcomes likely to be important to the board and the organization it governs.

\section{Implications for Research and Practice}

The results presented here provide evidence that board conflict has negative implications for organizational outcomes that fall under the close control of the board. It also appears that the negative implications of board conflict may extend to less proximal organizational outcomes as well, though the effects may not be as strong. These results suggest the utility of broadening the perspective of the governing board role beyond agency and resource dependence theory to incorporate both the strategy and policy decision-making roles the board serves and possible impediments to that decision-making (Goodstein, Gautam, and Boeker 1994; Brown 2005). The conclusions from this study are consistent with Forbes and Milliken's (1999) idea that boards can be characterized as "episodic decision-making groups that face complex tasks pertaining to strategic-

these dimensions. Because of low first-stage $F$-statistics, IV models could not be run for African American or white dependent variables. Across the remaining 6 models, only in the OLS models for African American subgroup growth was conflict statistically significant $(B=-0.81, p<0.01)$. 
issue processing” and are vulnerable to the "interaction difficulties that prevent groups from reaching their full potential” (492). Group conflict can interfere with the governing board’s capacity to execute its core functions, with potential consequences for important outcomes.

In utilizing this perspective, this study is among the first to link governing board decision processes to "real world" outcomes in either the public or private sector. Despite the conventional wisdom in the private, public and nonprofit literatures that board decision-making matters, it is uncommon in empirical research to illustrate the link between boards and outcomes with processoriented data. This paper finds evidence that some boards perform better than others, and that board performance can be linked in part to the degree to which the board achieves consensus in decisionmaking. As Daily, Dalton, and Cannella (2003) argued, shining light into the "black box” of board deliberations is necessary for our understanding of effective governance and to expand our conceptualization of the governance process.

As a practical matter, the results suggest that boards may benefit from finding ways to reduce conflict among members. A study of board change among Canadian nonprofit organizations found that board problems related to process and decision-making were more responsive to improvement efforts than other kinds of challenges (Brudney and Murray 1998). More to the point, in their study of business school work teams, De Church and Marks (2001) found that conflict management strategies were effective at moderating the impact of conflict on group performance. This finding is important because the employment of conflict reduction strategies is largely under the group’s control, and conflict management is a set of skills that can be learned and adopted (Wall and Callister 1995, 550). Gabris et al. (2000) suggested that such activities as team building, strategic planning and small group intervention exercises could be effective conflict management approaches. However, other work cautions that it is important to choose appropriate methods for 
lower conflict. For example, studies have found that groups employing the nominal group technique to restrain confrontation generally arrive at lower quality decisions (Amason 1996, 127).

Nevertheless, training or exercises related to improving interpersonal dynamics and achieving consensus may be useful investments. This refrain is a common one in qualitative studies of school boards (e.g., Carol et al. 1986; Danzberger, Kirst, and Usdan 1992; Land 2002). There is evidence that these kinds of boards, at least, take this suggestion seriously; approximately $69 \%$ of respondents to the school board survey used here said that they had received some kind of formal training in "working together as a board." However, the quality of the training many board members receive is circumspect (Land 2002), raising concerns about the degree to which many existing professional development opportunities are capable of improving board functioning.

More generally, the findings of this study support the contention that the field of public administration should devote more attention to conflict and its management at the highest levels of organizations, both in research and outreach. As Lan (1997) argues, work in the public sector is increasingly conflict-rich, yet its practitioners, schooled primarily in the technical-rational and political perspectives of public decision-making, "have not been adequately exposed to the skills and rationales of conflict resolution” (33), which handicaps them in serving the public interest. This criticism likely applies even more so to local elected governing board members, who often have little prior public experience or formal preparation (Land 2002). While conflict resolution has been a growth area in public administration research for several decades (see Lipsky and Avgar 2004) and conflict management systems for employees are becoming more common in public sector organizations (e.g., Bingham and Nabatchi 2003; Hebdon 1996; Nabatchi and Bingham 2010), this study suggests positive returns from greater application and study of conflict management principles at the highest organizational levels as well. 
Changes to board self-governance are not the only means for reducing board conflict. More harmonious relations can be promoted by choosing some institutional characteristics over others (Svara 1990). One example already provided is how board members are chosen. For example, boards elected in single-member districts have higher degrees of conflict than those elected at-large, possibly because single-member districts promote narrower representation of constituent interests by each board member (Grissom 2010; Welch and Bledsoe 1988). Evidence suggests that singlemember district elections may improve the board's responsiveness to and representation of minority populations within the district (e.g., Leal, Martinez-Ebers, and Meier 2004), but these improvements may come at the expense of increased conflict and worse outcomes on some dimensions.

\section{Limitations and Suggestions for Future Research}

An important limitation of this study is the degree to which research on school boards can be generalized. There are numerous ways in which school districts differ from other public organizations. Also, in several important aspects, school boards may not be typical of other governing boards. For example, they tend to be elected rather than appointed. Their heterogeneity is another example; public and nonprofit board members come disproportionately from business and industry, whereas school board members vary widely in their occupational and educational background (Hess 2002). Another difference is the pervasiveness of role confusion—school board members view themselves variously as trustees, representatives, and managers-which is a source of conflict among school board members (Danzberger, Kirst, and Usdan 1992). Roles for members of other kinds of governing boards may be better defined.

An additional concern about this study's findings is the interpretation of the results as causal. Even if the assumptions necessary for instrumental variables to yield unbiased estimates hold, the coefficients can only be interpreted as the local average treatment effect, not the general 
effect (Imbens and Angrist 1994). This distinction means that only the impact that is related to differences in the exogenous factor-election type-has been identified. Further analysis is necessary to specify the causal impact of group conflict that may derive from other sources. Still, the use of this institutional variation to get closer to illustrate the negative effects of board conflict is a substantial improvement over less sophisticated correlational methods.

Additional research is also necessary to more completely map the organizational pathways linking governing board decision-making to direct and indirect outcomes. The study makes an empirical connection between board conflict and organizational outcomes, but it only suggests possible mechanisms that link them. Further work is necessary to pinpoint how board conflict can lead to lower organizational performance. Moreover, there may be a number of variables that moderate the relationship between board conflict and outcomes. One potential source of moderators comes from viewing the board within its environmental and structural context, an essential piece of understanding governance (Lynn, Heinrich, and Hill 2001). For example, the role of the school board in the day-to-day functioning of a school district likely varies according to the size of the district, suggesting that enrollment size may moderate the relationship between board conflict and organizational outcomes. As another example, in other studies group conflict has had greater effects in complex task environments (De Dreu and Weingart 2003), suggesting that school board conflict may be more detrimental in districts facing more numerous obstacles to raising student achievement. $^{22}$

The results also suggest that investigation of the impact of board processes on other board and organizational outcomes would be a fruitful avenue of future research. For example, research could examine how well board functioning predicts the likelihood that board members choose to

\footnotetext{
${ }^{22}$ As one way to test for a moderating effect of task complexity, I attempted to test for an interaction between board conflict or consensus and the previous year's API score. Unfortunately, correlations between the conflict/consensus measures and the interaction terms ranged between 0.93 and 0.99 , making this test infeasible with this data set.
} 
run again for future terms or whether the public holds board members accountable for poor board performance by re-electing them at lower rates. It might also explore how board decision-making processes impact superintendent performance or the likelihood that the superintendent is retained by the district, including both voluntary and involuntary exits.

\section{Conclusions}

The long-standing interest in governing boards in the literature derives from the supposition that effective boards can drive organizational success. While the empirical challenges of linking board characteristics or behaviors to outcomes suggest that high-functioning boards are neither sufficient nor altogether necessary for organizations to perform at a high level, few doubt that, under the right conditions, boards can play a key role in an organization's capacity to reach its goals. However, there has been surprisingly little research across the public and private management literatures on the interpersonal aspects of board behavior or the implications of that behavior for how well the board functions (Brown 2005; Forbes and Milliken 1999).

This study suggests that attending to this interpersonal dimension and finding ways to encourage board consensus pays off, both for the board and for the organization. The empirical results are consistent with recommendations found in many popular books on effective board governance (e.g., Carver 2006). Conflict reduction and conflict management appear to be important strategies for board success, particularly in complex decision contexts. 


\section{Appendix}

Appendix Table 1: Correlations among Control Variables

(1) Fraction black
(2) Fraction Hispanic
(3) Fraction free/reduced lunch eligible
(4) $\ln$ (District size)
(5) Academic Performance Index score, 2005
(6) Per-pupil expenditures (in $\$ 1,000$ s)
(7) Unified district
(8) Urban
(9) Rural
(10) Median household income (in $\$ 10,000$ s)
(11) Fraction of adults who are college graduates
(12) Fraction of SB respondents reporting competitive elections

$\begin{array}{cccccccccccc}(1) & (2) & (3) & (4) & (5) & (6) & \text { (7) } & \text { (8) } & \text { (9) } & \text { (10) } & \text { (11) } & \text { (12) } \\ 1.00 & & & & & & & & & & & \\ 0.10 & 1.00 & & & & & & & & & & \\ 0.06 & 0.65 & 1.00 & & & & & & & & & \\ 0.41 & 0.37 & -0.00 & 1.00 & & & & & & & & \\ -0.18 & -0.66 & -0.72 & -0.26 & 1.00 & & & & & & & \\ -0.12 & -0.17 & -0.01 & -0.44 & 0.11 & 1.00 & & & & & & \\ 0.32 & 0.22 & 0.16 & 0.45 & -0.32 & 0.05 & 1.00 & & & & & \\ 0.19 & 0.20 & 0.05 & 0.52 & -0.10 & -0.17 & 0.18 & 1.00 & & & & \\ -0.28 & -0.39 & 0.04 & -0.66 & 0.12 & 0.26 & -0.20 & -0.38 & 1.00 & & & \\ -0.08 & -0.28 & -0.66 & 0.10 & 0.64 & 0.00 & -0.19 & 0.09 & -0.26 & 1.00 & & \\ -0.06 & -0.47 & -0.72 & 0.01 & 0.75 & 0.18 & -0.12 & 0.04 & -0.21 & 0.82 & 1.00 & \\ 0.34 & 0.24 & -0.05 & 0.59 & -0.19 & -0.14 & 0.26 & 0.43 & -0.48 & 0.09 & 0.05 & 1.00\end{array}$




\section{References}

Amason, Allan C. 1996. Distinguishing the effects of functional and dysfunctional conflict on strategic decision making: Resolving a paradox for top management groups. Academy of Management Journal 39: 123-148.

Amason, Allan C., and David Schweiger. 1994. Resolving the paradox of conflict, strategic decision making, and organizational performance. International Journal of Conflict Management 5: 239-253.

Amason, Allan C., and David Schweiger. 1997. The effect of conflict on strategic decision making effectiveness and organizational performance. In Using conflict in organizations, ed. Carsten K. W. De Dreu and Evert Van de Vliert, 101-115. London: Sage.

Avila, Joaquin G, Eugene Lee, and Terry M Ao. 2007. Voting rights in California: 1982-2006. Southern California Review of Law and Social Justice 17: 131-194.

Bertelli, Anthony M. 2007. Determinants of bureaucratic turnover intention: Evidence from the Department of the Treasury. Journal of Public Administration Research and Theory 17(2): 235-258.

Bingham, Lisa Blomgren, and Tina Nabatchi. 2003. Dispute system design in organizations. In J. Killian and W.J. Pammer, eds., The Handbook on Conflict Management (pp. 105-127), New York: Marcel Dekker.

Björk, Lars. 2008. Leading in an era of change: The micropolitics of superintendent-board relations. In T. Alsbury (ed.), The Future of School Board Governance: Relevancy and Revelation, Lanham, MD: Rowman \& Littlefield.

Black, Duncan. 1958. The Theory of Committees and Elections. Cambridge: Cambridge University Press.

Bradshaw, Pat, Vic Murray, and Jacob Wolpin. 1992. Do nonprofit boards make a difference? An exploration of the relationships among board structure, process, and effectiveness. Nonprofit and Voluntary Sector Quarterly 21: 227-249.

Brown, William A. 2005. Exploring the association between board and organizational performance in nonprofit organizations. Nonprofit Management \& Leadership 15: 317-339.

Brudney, Jeffrey L., and Vic Murray. 1998. Do intentional efforts to improve boards really work? Nonprofit Management \& Leadership 8: 333-348.

Carnevale, Peter, and Tahira M. Probst. 1998. Social values and social conflict in creative problem solving and categorization. Journal of Personality and Social Psychology 74: 1300-1309.

Carol, Lila, Luvern Cunningham, Jacqueline Danzberger, Michael Kirst, Barbara McCloud, and Michael Usdan. 1986. School boards: Strengthening grass roots leadership. Washington, D.C.: IEL, Inc.

Carver, John. 2006. Boards that make a difference ( $3^{\text {rd }}$ ed.). San Francisco: Jossey-Bass.

Chait, Richard, Thomas Holland, and Barbara Taylor. 1991. The effective board of trustees. New York: Macmillan.

Cornforth, Chris. 2001. What makes boards effective? An examination of the relationships between board inputs, structures, processes and effectiveness in non-profit organisations. Corporate Governance 9: 217-227. 
Cotton, John L., and Jeffrey M. Tuttle. 1986. Employee turnover: A meta-analysis and review with implications for research. Academy of Management Review 11(1): 56-70.

Daily, Catherine M., Dan R. Dalton, and Albert A. Cannella, Jr. 2003. Corporate governance: Decades of dialogue and data. The Academy of Management Review 28: 371-382.

Danzberger, Jacqueline P. 1994. Governing the nation’s schools. Phi Delta Kappan 75(5): 367-373.

Danzberger, Jacqueline P., Michael W. Kirst, and Michael D. Usdan. 1992. Governing public schools: New times, new requirements. Washington, DC: Institute for Educational Leadership.

De Church, Leslie A., and Michelle A. Marks. 2001. Maximizing the benefits of task conflict: The role of conflict management. International Journal of Conflict Management 12: 4-22.

De Dreu, Carsten K. W., and Laurie Weingart. 2003. Task versus relationship conflict, team performance, and team member satisfaction: A meta-analysis. Journal of Applied Psychology 88: 741-749.

De Dreu, Carsten K. W., and Michael A. West. 2001. Minority dissent and team innovation: The importance of participation in decision making. Journal of Applied Psychology 86: 11911201.

Downs, Anthony. 1957. An Economic Theory of Democracy. New York: Harper \& Row.

Forbes, Daniel P., and Frances J. Milliken. 1999. Cognition and corporate governance: Understanding boards of directors as strategic decision-making groups. The Academy of Management Review 24: 489-505.

Gabris, Gerald T., Keenan Grenell, Douglas M. Ihrke, and James Kaatz. 2000. Managerial innovation at the local level: Some effects of administrative leadership and governing board behavior. Public Productivity \& Management Review 23: 486-494.

Goodman, Richard H., Luann Fulbright, and William G. Zimmerman, Jr. 1997. Getting there from here: School board-superintendent collaboration: Creating a school governance team capable of raising student achievement. Arlington, VA: Educational Research Service and New England Staff Development Council.

Goodstein, Jerry, Kanak Gautam, and Warren Boeker. 1994. The effects of board size and diversity on strategic change. Strategic Management Journal 15: 241-250.

Grissom, Jason A. 2010. The determinants of conflict on governing boards in public organizations: The case of California school boards. Journal of Public Administration Research and Theory 20(3): 601-627.

Grissom, Jason A. 2011. Can good principals keep teachers in disadvantaged schools? Linking principal effectiveness to teacher satisfaction and turnover in hard-to-staff environments. Teachers College Record 113: 2552-2585.

Hebdon, Robert. 1996. Public sector dispute resolution in transition. In D. Belman, M. Gunderson, and D. Hyatt, eds., Public Sector Employment Relations in a Time of Transformation. Madison, WI: Industrial Relations Research Association.

Hess, Frederick. 2002. School boards at the dawn of the 21st century. Alexandria, VA: National School Boards Association. 
Hillman, Amy, and Thomas Dalziel. 2003. Boards of directors and firm performance: Integrating agency and resource dependence perspectives. The Academy of Management Review 28: 383-396.

Ihrke, Douglas M., and M. Scott Niederjohn. 2005. Conflict on city councils in Wisconsin. Journal of Urban Affairs 27: 453-462.

Imbens, Guido W., and Joshua D. Angrist. 1994. Identification and estimation of local average treatment effects. Econometrica 62(2): 467-475.

Ingersoll, Richard. 2001. Teacher turnover and teacher shortages: An organizational analysis. American Educational Research Journal 38(3): 499-534.

Jehn, Karen. 1994. Enhancing effectiveness: An investigation of advantages and disadvantages of value-based intragroup conflict. International Journal of Conflict Management 5: 223-238.

Jehn, Karen. 1995. A multimethod examination of the benefits and detriments of intragroup conflict. Administrative Science Quarterly 40: 256-282.

Jehn, Karen. 1997. A qualitative analysis of conflict types and dimensions in organizational groups. Administrative Science Quarterly 42: 530-557.

Jehn, Karen, Clint Chadwick, and Sherry M. B. Thatcher. 1997. To agree or not to agree: The effects of value congruence, individual demographic dissimilarity, and conflict on workgroup outcomes. International Journal of Conflict Management 8: 287-305.

Jehn, Karen, Gregory B. Northcraft, and Margaret A. Neale. 1999. Why differences make a difference: A field study of diversity, conflict, and performance in workgroups. Administrative Science Quarterly 44: 741-763.

Kacmar, K. Michele, Martha C. Andrews, David L. Van Rooy, R. Chris Steilberg, and Stephen Cerrone. 2006. Sure everyone can be replaced . . . but at what cost? Turnover as a predictor of unit-level performance. Academy of Management Journal 49(1): 133-144.

Kirst, Michael. 1994. A changing context means school board reform. Phi Delta Kappan 75(5): 378-381.

Lan, Zhiyong. 1997. A conflict resolution approach to public administration. Public Administration Review 57(1): 27-35.

Land, Deborah. 2002. Local school boards under review: Their role and effectiveness in relation to students' academic achievement. Review of Educational Research 72: 229-278.

Leal, David L., Valerie Martinez-Ebers, and Kenneth J. Meier. 2004. The politics of Latino education: The biases of at-large elections.” Journal of Politics 66: 1224-1244.

Lipsky, David B., and Ariel C. Avgar. 2004. Research on employment dispute resolution: Toward a new paradigm. Conflict Resolution Quarterly 22(1-2): 175-189.

Lynn, Laurence E., Jr., Carolyn Heinrich, and Carolyn Hill. 2001. Improving governance: A new logic for empirical research. Washington, DC: Georgetown University Press.

Merz, Carol. 1986. Conflict and frustration for school board members. Urban Education 20(4): 397418.

Mobley, William H. 1982. Employee turnover: Causes, consequences, and control. Reading, MA: Addison-Wesley. 
Nabatchi, Tina, and Lisa Blomgren Bingham. 2010. From postal to peaceful: Dispute systems design in the USPS REDRESS program. Review of Public Personnel Administration 30(2): 211-234.

Pearce, II, John A., and Shaker A. Zahra. 1991. The relative power of CEOs and boards of directors: Associations with corporate performance. Strategic Management Journal 12: 135153.

Pfeffer, Jeffrey, and Gerald Salancik. 1978. The external control of organizations. New York: Harper \& Row.

Polinard, J. L., Robert D. Wrinkle, Tomas Longoria, and Norman Binder. 1994. Electoral structure and urban policy. New York: M. E. Sharpe.

Staiger, Douglas, and James H. Stock. 1997. Instrumental variables regression with weak instruments. Econometrica 65: 557-586.

Sundaramurthy, Chamu, and Marianne Lewis. 2003. Control and collaboration: Paradoxes of governance. The Academy of Management Review 28: 397-415.

Svara, James. 1990. Official leadership in the city. New York: Oxford University Press.

Thomas, Kenneth W. 1992. Conflict and negotiation processes in organizations. In Handbook of industrial and organizational psychology, ed. Marvin D. Dunnette and Leaetta M. Hough, 651-717. Palo Alto, CA: Consulting Psychologists Press.

Wall, Jr., James, and Rhonda Callister. 1995. Conflict and its management. Journal of Management 21: $515-558$.

Westphal, James D. 1999. Collaboration in the boardroom: Behavioral and performance consequences of CEO-board social ties. The Academy of Management Journal 42: 7-24.

Welch, Susan. 1990. The impact of at-large elections on the representation of blacks and Hispanics. Journal of Politics 52(4): 1050-1076.

Welch, Susan, and Timothy Bledsoe. 1988. Urban reform and its consequences. Chicago: University of Chicago Press.

Wooldridge, Jeffrey M. 2002. Econometric analysis of cross section and panel data. Cambridge, MA: MIT Press. 


\section{Figure 1: Board Conflict and Subjective Evaluations of Board Effectiveness and Board-Executive Relations}
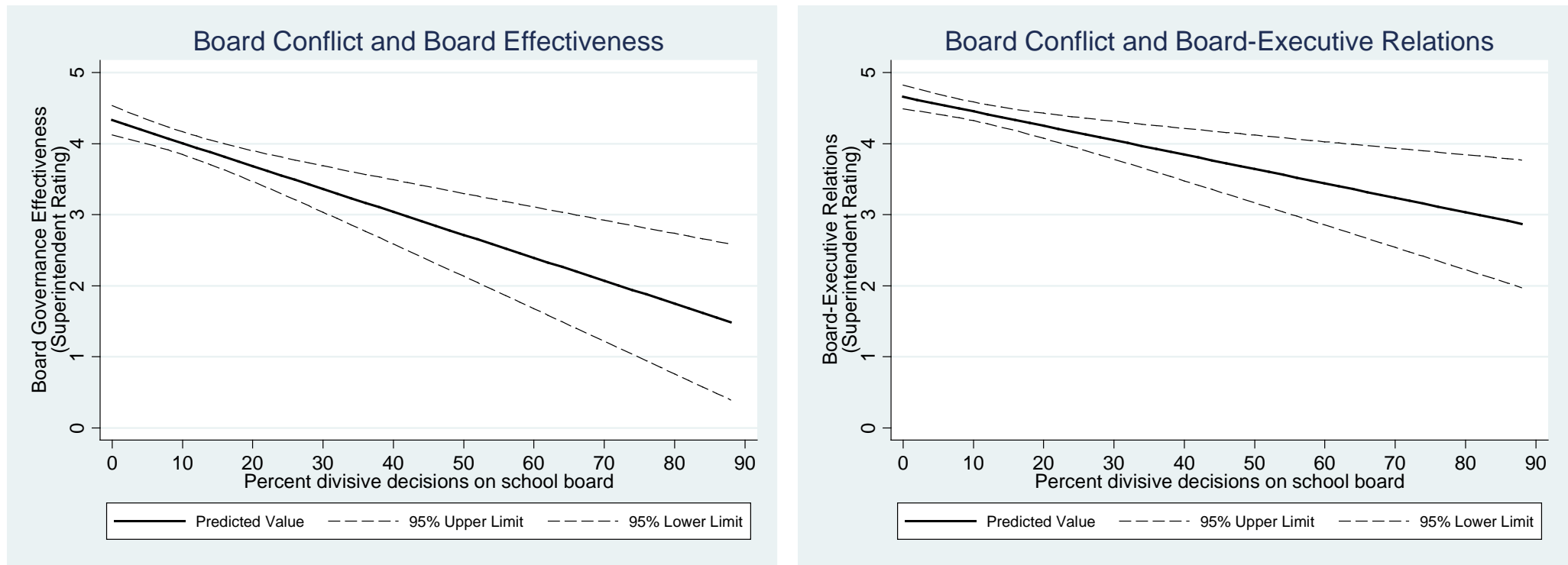
Table 1: Descriptive Statistics

\begin{tabular}{|c|c|c|c|c|c|}
\hline Variables & $\mathrm{N}$ & Mean & SD & Min & Max \\
\hline \multicolumn{6}{|l|}{ Conflict Measures } \\
\hline Percent divisive decisions (SB) & 124 & 9.43 & 12.31 & 0 & 95 \\
\hline School board decisions characterized by consensus (SUPT) & 124 & 3.99 & 1.05 & 1 & 5 \\
\hline \multicolumn{6}{|l|}{ Dependent Variables } \\
\hline School board effectiveness rating (SUPT) & 124 & 4.02 & 1.08 & 1 & 5 \\
\hline School board effectiveness rating (SB) & 124 & 4.12 & 0.64 & 1 & 5 \\
\hline Relationship between board and superintendent (SUPT) & 123 & 4.46 & 0.8 & 1 & 5 \\
\hline Relationship between board and superintendent (SB) & 124 & 4.41 & 0.65 & 1.5 & 5 \\
\hline Teacher turnover a problem in district & 124 & 2.06 & 0.83 & 1 & 4.6 \\
\hline Academic Performance Index (API) Growth (2005-06) & 124 & 10.84 & 16.44 & -72 & 71 \\
\hline \multicolumn{6}{|l|}{ Control Variables } \\
\hline Fraction African American students in district & 124 & 0.04 & 0.05 & 0 & 0.29 \\
\hline Fraction Hispanic students in district & 124 & 0.31 & 0.25 & 0 & 0.99 \\
\hline Fraction free/reduced lunch students in district & 124 & 0.42 & 0.24 & 0 & 0.99 \\
\hline $\ln ($ District size $)$ & 124 & 7.59 & 1.73 & 3.24 & 11.18 \\
\hline Academic Performance Index level (2005) & 124 & 743.85 & 75.99 & 587 & 945 \\
\hline Per pupil spending (in $\$ 1,000$ s) & 124 & 7.41 & 2.08 & 5.49 & 18.94 \\
\hline Unified (K-12) district & 124 & 0.36 & 0.48 & 0 & 1 \\
\hline Urban & 124 & 0.18 & 0.38 & 0 & 1 \\
\hline Rural & 124 & 0.40 & 0.49 & 0 & 1 \\
\hline Median household income (in $\$ 1,000$ s) & 124 & 4.77 & 1.94 & 1.97 & 16.21 \\
\hline Fraction adults who are college graduates in district & 124 & 0.23 & 0.14 & 0.02 & 0.77 \\
\hline Fraction of school board elections that are competitive & 124 & 0.40 & 0.40 & 0 & 1 \\
\hline
\end{tabular}

Parenthetical notation indicates respondent type $(S B=$ school board, $S U P T=$ superintendent $)$. 
Table 2: Intra-Board Conflict and Governance Effectiveness

\begin{tabular}{|c|c|c|c|c|}
\hline & $(1)$ & $(2)$ & $(3)$ & $(4)$ \\
\hline Dependent Variable: & \multicolumn{2}{|c|}{$\begin{array}{l}\text { Superintendent's Rating } \\
\text { of Board Effectiveness }\end{array}$} & \multicolumn{2}{|c|}{$\begin{array}{l}\text { Board's Average Self- } \\
\text { Rating of Effectiveness }\end{array}$} \\
\hline Estimation Method: & OLS & IV & OLS & IV \\
\hline Percent divisive decisions on school board (SB) & $\begin{array}{c}-0.0323 * * * \\
(0.00705)\end{array}$ & $\begin{array}{c}-0.0406 * * * \\
(0.0183)\end{array}$ & & \\
\hline School board decisions characterized by consensus (SUPT) & & & $\begin{array}{l}0.270 * * * \\
(0.0539)\end{array}$ & $\begin{array}{c}0.392 * * * \\
(0.167)\end{array}$ \\
\hline Constant & $\begin{array}{l}3.697^{*} \\
(2.008)\end{array}$ & $\begin{array}{l}4.002 * * \\
(2.003)\end{array}$ & $\begin{array}{l}2.659 * * \\
(1.195)\end{array}$ & $\begin{array}{l}2.475 * * \\
(1.176)\end{array}$ \\
\hline Observations & 124 & 124 & 124 & 124 \\
\hline Adjusted $\mathrm{R}^{2}$ & 0.286 & & 0.286 & \\
\hline First stage F statistic & & 16.9 & & 11.7 \\
\hline $\begin{array}{l}\text { Standard errors in parentheses. }{ }^{* *} p<0.01, * * p<0.05, * p<0.10 \text { (o) } \\
\text { students, fraction Hispanic students, fraction free/reduced price lunc } \\
\text { Performance Index (API) level for the district, per-pupil expenditures } \\
\text { household income, the percent of adults in the district who are colleg } \\
\text { are competitive. }\end{array}$ & $\begin{array}{l}\text { stailed }) \text {. All } m \\
\text { students, } \ln (d i \\
\text { graduates, rural, } \mathrm{anc}\end{array}$ & $\begin{array}{l}\text { dels include } c \\
\text { trict size), the } \\
\text { nified (K-12) } d \\
\text { the fraction o }\end{array}$ & $\begin{array}{l}\text { ntrols for fra } \\
005 \text { Academ } \\
\text { trict, the dis } \\
\text { school board }\end{array}$ & $\begin{array}{l}\text { on black } \\
\text { ect's median } \\
\text { ections that }\end{array}$ \\
\hline
\end{tabular}


Table 3: Intra-Board Conflict and Board-Executive Relations

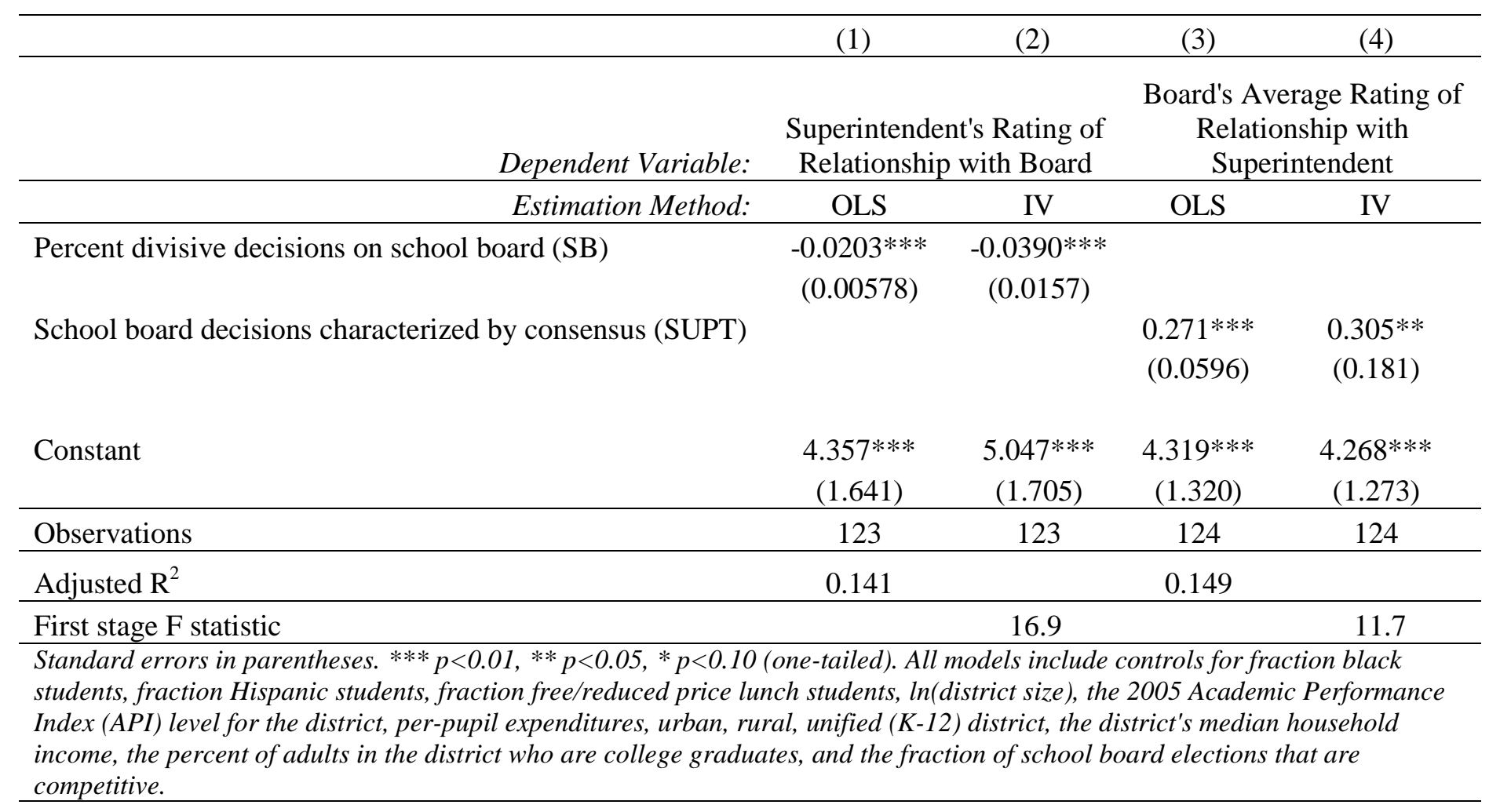


Table 4: Intra-Board Conflict and Intermediate and Final Organizational Outcomes

\begin{tabular}{|c|c|c|c|c|c|c|c|c|}
\hline \multirow{3}{*}{$\begin{array}{r}\text { Dependent Variable: } \\
\text { Estimation Method: }\end{array}$} & $(1)$ & $(2)$ & $(3)$ & $(4)$ & $(5)$ & $(6)$ & $(7)$ & $(8)$ \\
\hline & \multicolumn{4}{|c|}{ Teacher Turnover a Problem in District } & \multicolumn{4}{|c|}{$\begin{array}{c}\text { Academic Performance Index (API) } \\
\text { Growth (2005-06) }\end{array}$} \\
\hline & OLS & IV & OLS & IV & OLS & IV & OLS & IV \\
\hline Percent divisive decisions on school board (SB) & $\begin{array}{l}0.0192 * * * \\
(0.00590)\end{array}$ & $\begin{array}{c}0.0384 * * * \\
(0.0160)\end{array}$ & & & $\begin{array}{c}-0.00214 \\
(0.129)\end{array}$ & $\begin{array}{l}-0.0104 \\
(0.333)\end{array}$ & & \\
\hline $\begin{array}{l}\text { School board decisions characterized by } \\
\text { consensus (SUPT) }\end{array}$ & & & $\begin{array}{l}-0.0996 * \\
(0.0783)\end{array}$ & $\begin{array}{c}-0.578 * * * \\
(0.275)\end{array}$ & & & $\begin{array}{l}2.974^{* *} \\
(1.625)\end{array}$ & $\begin{array}{r}0.156 \\
(5.000)\end{array}$ \\
\hline Constant & $\begin{array}{l}2.889 * \\
(1.681) \\
\end{array}$ & $\begin{array}{c}2.187 \\
(1.745) \\
\end{array}$ & $\begin{array}{l}3.744 * * \\
(1.737) \\
\end{array}$ & $\begin{array}{l}4.470 * * \\
(1.934)\end{array}$ & $\begin{array}{r}3.996 \\
(36.75) \\
\end{array}$ & $\begin{array}{c}4.297 \\
(36.42) \\
\end{array}$ & $\begin{array}{l}-0.597 \\
(35.99)\end{array}$ & $\begin{array}{r}3.682 \\
(35.11) \\
\end{array}$ \\
\hline Observations & 124 & 124 & 124 & 124 & 124 & 124 & 124 & 124 \\
\hline Adjusted $\mathrm{R}^{2}$ & 0.163 & & 0.0954 & & 0.081 & & 0.02 & \\
\hline First stage F statistic & & 16.9 & & 11.7 & & 16.9 & & 11.7 \\
\hline $\begin{array}{l}\text { Standard errors in parentheses. } * * * p<0.01, * * p<0.0 \\
\text { students, fraction free/reduced price lunch students, Ir } \\
\text { urban, rural, unified }(K-12) \text { district, the district's med } \\
\text { school board elections that are competitive. }\end{array}$ & $\begin{array}{l}5, * p<0.10(c \\
\text { (district size), } \\
\text { an household }\end{array}$ & $\begin{array}{l}\text { ne-tailed). Al } \\
\text { the } 2005 \text { Aca } \\
\text { ncome, the } p\end{array}$ & $\begin{array}{l}\text { models incl } \\
\text { mic Perfor } \\
\text { cent of adu }\end{array}$ & $\begin{array}{l}\text { de controls fo } \\
\text { nance Index } \\
\text { ts in the distri }\end{array}$ & $\begin{array}{l}\text { action blac } \\
\text { I) level for } t \\
\text { who are coll }\end{array}$ & $\begin{array}{l}\text { students, } f \\
\text { district, } f \\
\text { e graduat }\end{array}$ & $\begin{array}{l}\text { ction Hisp } \\
\text {-pupil exp } \\
\text { and the } f\end{array}$ & $\begin{array}{l}\text { ic } \\
\text { ditures, } \\
\text { tion of }\end{array}$ \\
\hline
\end{tabular}

